\title{
Evaluating Competition Constraint on Land Accessibility by Urban Crop Farmers in Lagos
}

\author{
Odudu, C.O. ${ }^{1, *}$ \\ ${ }^{1}$ Department of Estate Management, University of Benin, Benin City, Nigeria \\ Corresponding Author: *christopher.odudu@uniben.edu
}

\begin{abstract}
The study evaluated the constraint of competition on urban crop farming in Lagos with a view to identifying issues that must be resolved to facilitate practitioners' land accessibility in the metropolis. Crop farmers in seven out of ten communities where urban crop farming was found to be thriving within the metropolis were selected through multi-stage sampling which involved both purposive and simple random samplings and were administered with structured questionnaires. All the farming communities were delineated by the Lagos State Agricultural Development Authority (LSADA). Data collected were analysed using descriptive statistics while linear regression analysis was used to test the formulated research hypothesis. The study showed that farmers were forced out (19.5\%) of their locations, $10.3 \%$ vacated voluntarily, $1.4 \%$ left due to high rents, $2.9 \%$ unidentified and $67.8 \%$ were missing values. Urban farmers in the study area were, however, found not to be affected by competition and high rents as they were occupying marginal lands that did not attract other competing uses. The regression analysis showed that competition constraint accounted for $3.5 \%$ of farmers' productivity establishing that competition with other uses significantly affected urban farmers' productivity as they were consigned to marginal lands. The study therefore concluded that government should support/promote the activity by providing agricultural lands in designated areas of the metropolis for urban farming.
\end{abstract}

Keywords: Land Accessibility, Urban Crop Farming, Competition Constraint, Farmers' productivity, Lagos

\subsection{Introduction}

The land mass of Lagos has not responded to the exponential population that is the bane of Lagos in the last few years. Since its creation in 1967, its population has grown from 665,000 in 1963 (Abiodun, 1997) to over $9,013,534$ as recorded by the 2006 national population census exercise although Lagos State claims that its population is over 21 million people currently (LASG, 2015). Thus, the available land mass of 109,840 hectares trigger fierce competition among the various land uses for residential, commercial and industrial developments. Urban crop farming as an informal sector activity (Ndi, 2009) is therefore not considered a proper land use and is largely unrecognized for official land use zoning. In this paper, urban crop farming is used interchangeably with urban farming and urban agriculture. The activity is located in the informal sector, it's generally land-based and is recognized world-wide as a farming practice in the towns and cities of developing and developed countries. Mosha (2015) noted that in spite of the low prevalence of urban and peri-urban agriculture (UPA) in Botswana, the sector has received attention from both central and local governments and that government has been working towards formulating a policy on UPA since the 2000s. Urban farming affords households selfsufficiency in food, income and employment generation. It is a source of local and fresh farm produce and short-seasoned crops such as maize, yams, vegetables, tomatoes and groundnuts. UN-Habitat (2008), in deed, reported that between 15 and $20 \%$ of the world's food is produced by some 800 million urban and peri-urban farmers and gardeners. Urban farming is defined as "an industry located within (intra-urban) or on the fringe (peri-urban) of towns, urban centers or cities, which grows or raises, processes and distributes a diversity of food and non-food products, reusing mainly human and material 
resources, products and services found in and around that urban area, and in turn supplying human and material resources, products and services largely to that urban area" (Mougeot, 2000; Knowd et al., 2006). In spite of all the positive contributions to a city's development, Tinsley (2003) noted that urban farmers do not generally have access to land as they are unable to compete with other uses for the highvalued lands. Landownership in Lagos is considered by Akinmoladun and Adejumo (2011) to be in four strata, that is, federal, state, local and private individuals. They went on to establish that government agencies, 'have a lot of disused plots, unplanned open spaces and buffer land that can be put to productive urban agriculture estimated at 105ha'. Although most lands are owned by government, urban crop farmers have no easy access to land for the activity. Odudu et al. (2015) also opined that one of the most critical issues urban farmers are contending with is competition with other uses. Competition constraint in land accessibility indicates whether the urban farmer can achieve a quiet and peaceful enjoyment of his land to carry on the activity. Competition for land is rife particularly for sites that enjoy first class locations such as the central business districts (CBDs) and well-planned layouts. The urban farmer is therefore faced with the highest bidder who easily outbids him for a site as he/she may not have enough money to compete with other uses (residential, commercial and industrial) for the available land. The competition criterion is further measured by rate of change of farm location, period of farming in the location, reasons for vacating the land, activity replacing the farmland as well as the rate of change of use. Land is known to be very critical to the survival of urban farming, although other methods such as hydroponics (a method of growing crops in nutrient solutions rather than in soil) have been developed in cities and towns experiencing acute shortage of arable land (van Veenhuzen, 2006). The lack of good access to suitable and usable land has made urban farmers resort to marginal lands such as wetlands, riverbanks, those with poor topography and road buffers. According to Ukaejiofo (2010), land governance is a consequence of access to land, its use and satisfaction of competing interests. Velez-Guerra (2004) in Bamako (Mali) identified multiple means of accessing land for urban agriculture as formal, informal and semi-informal methods. He concluded that urban crop farmers are accessing land through renting, inheritance, borrowing, squatting, leasing and spontaneous occupation. These modes of access were also reiterated by Crush et al. 2011) while Aina et al. (2012) found that urban farmers access land through personal ownership (32.86\%), borrowing $(21.42 \%)$, renting $(31.42 \%)$ and leasing $(14.29 \%)$ showing that more farmers rented (45.71\%) compared with those on personal ownership or borrowing.

Researchers (Foeken and Owuor, 2000; Drechsel and Dongus, 2009; Mosha, 2015) have noted the positive contributions of urban agriculture or urban crop farming to towns and cities of developed countries but the activity is yet to gain grounds in developing countries where it would be most beneficial because of obvious food security problems, increasing uncontrolled urbanization, population explosion and increasing youth unemployment. Reuther and Dewar (2005) and Asiama ((2005) noted that the greatest hindrance to urban farming is its inaccessibility to land as well as the attitude of policy makers to the cause of the activity while Angotti's (2015) study in New York City noted that, 'the principal deterrent to agricultural production is the high cost of land'. In Nigeria, land accessibility is governed by the Land Use Act Cap L.5 2004 (Decree 6, 1978) which vests all lands in each state in the hands of the state governor for the benefit of all Nigerians irrespective of tribe, religion, occupation, level of education, political affiliation and gender. This method of land accessibility has not worked in practical terms as there is no specific provision in the 1978 Act for land use particularly for the informal sector which includes urban farming. The 1978 Act purports to guarantee access to land for both private and public uses but Bello (2007) noted that access to land is not only determined by law but also by the socio-economic characteristics of the person applying for land. Contrary to the spirit of the 1978 Act which requires that land be obtained mainly through government allocations, land is still being freely sold in the open market till today. Advertisements by estate surveyors, estate agents and other land agents show that land is sold from N500,000 to over N50 million per plot within planned areas of the Lagos metropolis while those in the unplanned areas command lower prices (Castles, 2016). Agriculture is without doubt perceived by policy makers as an artifact of rural life that simply does not belong in cities; public health nuisance; and being of marginal importance to the urban economy (Sanyal, 1985; Freeman, 1991). This connotes lack of recognition of the importance of urban farming to urban households in terms of employment opportunities, alternative source of employment to retirees, 
food security and complementary wage/income factor (Odudu, 2007). Land as an important factor in urban food production is obviously outside the reach of urban crop farmers as most of them are generally poor (van Veenhuizen, 2006). Angotti (2015) remarked that New York City which is branded as, 'the real estate capital of the world with available abundant investment capital has historically driven the high price of land in the city making less intensive uses such agriculture infeasible'. The term competition as explained by OALD (2001) is a situation in which people or organizations compete with each other for something that not everyone has while Merriam-Webster (2016) defined competition as, 'the act or process of trying to get or win something that someone else is also trying to get or win' or its simply a contest between rivals. Urban crop farming is unofficially at rivalry with other land uses like residential, commercial and industrial activities in a quest to gain access to the scarce land resource. Omomoh and Adeofun (2005) in their study noted that practitioners of urban farming are largely affected by population growth, urban expansion and competition from other uses. Practitioners face a high rate of change of use or location or are simply forced out of their farming locations by unnecessary competition. Bello (2007) also noted that the greatest problem facing groups in the informal sector which include urban farmers is accessibility to land as they suffer marginalization on the basis of education, occupation type and income in their efforts to access both government and private lands. Mosha (2015) further averred that a major challenge to the viability of UPA is land availability and access. He added that population densities give rise to competition and conflicts over land and natural resources. Owing to non-governmental support or recognition, urban crop farmers do not possess land ownership documents such as a certificate of occupancy and therefore cannot secure bank loans to improve on productivity or to build more permanent structures. The ubiquity of urban farming has, however, endeared it to parklands, open spaces within the community, steep slopes, wetlands, rivers, lakes, roads and rights-of-way such as power lines, gas lines, railways, buffers zones at airports and industrial complexes (Nasr, 1996). This paper presents issues of equitable land distribution to all uses whether in the formal or informal sector and the use of urban farming to solving food security, income generation and unemployment problems by enhancing the productivity of urban farmers. The paper, therefore, poses the question whether competition constraint in land accessibility affects the productivity of urban farmers? The paper shall also resolve the hypothesis that competition constraint has no significant effect on urban farmers' productivity. The study was consequently carried out as shown in the next section.

\subsection{Study Area}

The study is limited to metropolitan Lagos which is home to many companies and industries and located in the south-western part of Nigeria. Oni (2001) defined the boundaries of metropolitan Lagos as consisting of the territory within Latitudes $6^{\circ} 23^{\prime} \mathrm{N}$ and $6^{\circ} 41^{\prime} \mathrm{N}$ and Longitudes $3^{\circ} 09^{\prime} \mathrm{E}$ and $3^{\circ} 20^{\prime} \mathrm{E}$. Olayiwola et al. (2005) also noted that the Lagos lagoon stretches through the eastern boundary; bounded in the south by the Atlantic Ocean while the northern boundary has the landmass of Ikorodu local government area and Alagbado towards Abeokuta axis in Ifako-Ijaiye local government area. Badagry and Republic of Benin define the Western boundary. Metropolitan Lagos constitutes over $1,140 \mathrm{~km}^{2}$ (or one-third) of the total land mass $\left(3,577 \mathrm{~km}^{2}\right)$ of Lagos State. Lagos has since ceased to be Nigeria's capital but continues to impact on the nation's economic development. It is still the commercial nerve centre of Nigeria as more than half of Nigeria's industrial capacity is located here. In the post-structural adjustment programme (SAP) era, many of the companies and industries closed business leading to continuous retrenchments by both private and public sectors, thus, increasing the population of people in the informal sector and making metropolitan Lagos a good location for this study. The pressure on land by the various uses is over-whelming and distribution of land in the metropolis is relatively uneven against urban crop farming. As regards spatial distribution of urban farming communities, the Lagos State Agricultural Development Authority (LSADA) demarcated Lagos State into three agricultural blocs as eastern, western and far western blocs. The western bloc which lies within the Lagos metropolis has a high population of urban crop farmers distributed in ten agricultural circles with each circle consisting of three cells or farming communities. Communities identified for the study included Adiyan, Iju/Grailland, Ayobo/Aboru, Idimu/Powerline, PWD Ikeja, Volkswagen/Ojo and Festac Town. (See Figure 1). 


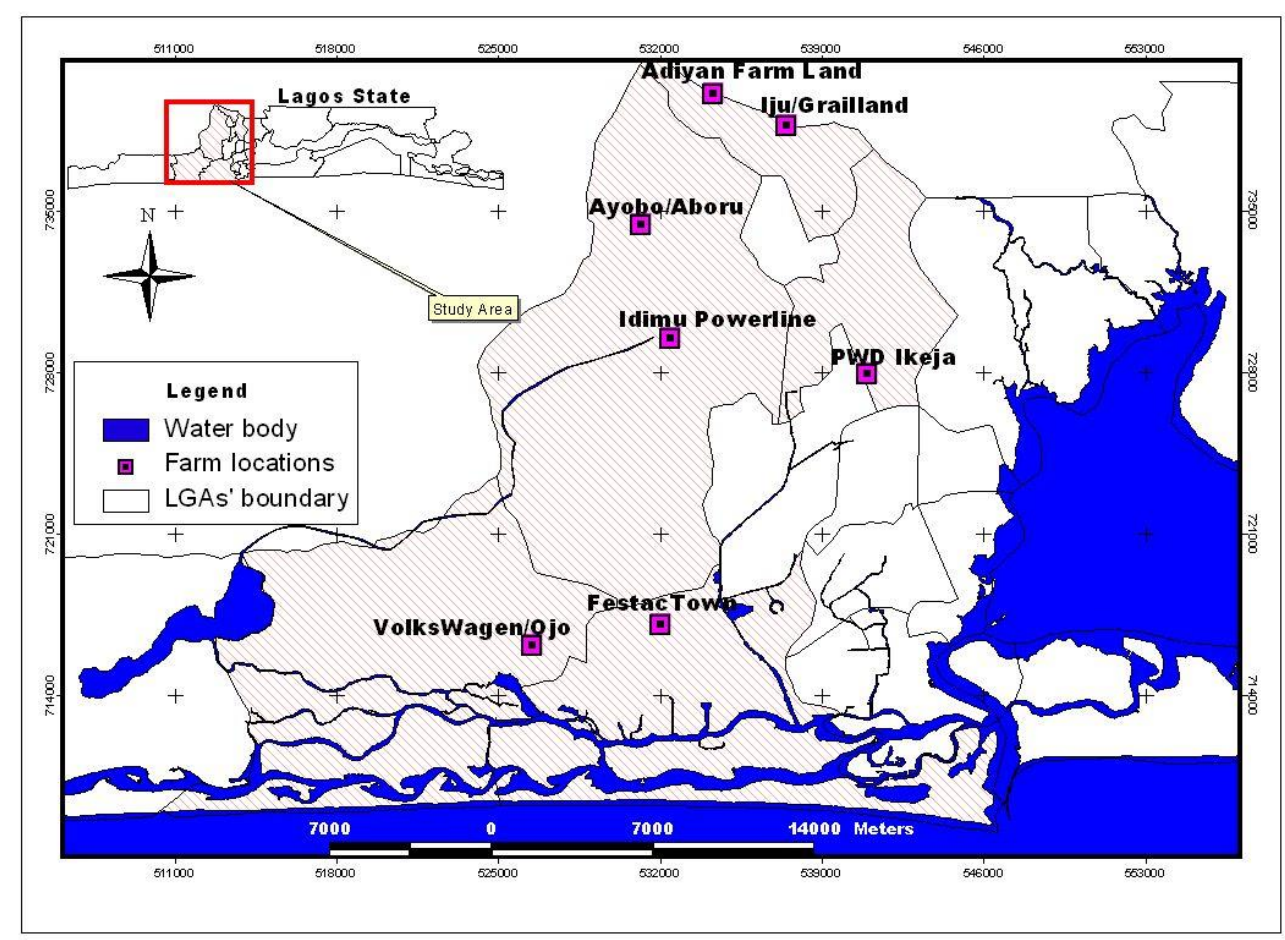

Figure 1: Metropolitan Lagos Showing the Study Locations

(Source: Geography Department, University of Lagos, 2012)

\subsection{Materials and Methods}

The study population consisted of all the practitioners of urban crop farming in the western agricultural bloc (Figure 1). Multi-stage sampling was adopted for the selection of sample size because of the complexity of the population of farmers which was distributed all over the Lagos metropolis. Purposive sampling was firstly used in this study to select seven agricultural circles from the ten circles in the western bloc or study area. Secondly, a cell or farming community was randomly selected from each circle of three cells. This gave a total of seven farming communities.

Lists of registered urban crop farmers in each farming community were obtained from the Lagos State Agricultural Development Authority Headquarters in Oko-Oba, Agege to enable the determination of the sample size in each farming community (Figure 1). The elements or respondents in each farming community were selected through simple random sampling from each stratum. Thus, the sample size for each population of farmers in a farming community was determined using Kish (1965) equation (see also Moore et al., 2003; Nirab, 2007) which noted as follows:

$\mathrm{N}=\mathrm{n}^{\prime}\left[1+\left(\mathrm{n}^{\prime} / \mathrm{N}\right)\right]$

Where:

$\mathrm{N}=$ total population (of each farming community) is recorded in the register

$\mathrm{n}=$ sample size from finite population

$\mathrm{n}^{\prime}=$ sample size from infinite population calculated from the formula $\left[\mathrm{n}^{\prime}=\mathrm{S}^{2} / \mathrm{V}^{2}\right]$

$\mathrm{S}^{2}=$ standard error of population elements, $\mathrm{S}^{2}=\mathrm{P}(1-\mathrm{P})$; maximum at $\mathrm{P}=0.5$

$\mathrm{V}^{2}=$ standard error of sample population equals 0.05 for the confidence level of $95 \%=1.96$

$\mathrm{n}^{\prime}=\mathrm{S}^{2} / \mathrm{V}^{2}=(0.5)^{2} /(0.05)^{2}=100$ 
Table 1: Urban farmers' population, sample size and response rate

\begin{tabular}{lccc}
\hline $\begin{array}{l}\text { Farming } \\
\text { Communities }\end{array}$ & Population & Sample size & $\begin{array}{c}\text { No. of } \\
\text { Questionnaires }\end{array}$ \\
\hline Adiyan & 120 & 55 & 26 \\
Iju/Grailland & 56 & 36 & 17 \\
Ayobo/Aboru & 45 & 31 & 17 \\
Idimu/Powerline & 55 & 36 & 17 \\
PWD Ikeja & 150 & 60 & 44 \\
Volkswagen/Ojo & 325 & 77 & 98 \\
Festac Town & 430 & 81 & 129 \\
\hline Total & 1,181 & 376 & 348 \\
\hline
\end{tabular}

Presented in Table 1 is the sample frame, sample size and questionnaires returned by the farmers. Copies of structured questionnaire were administered to a total of 376 respondents in the farming communities. Interview schedules with the farmers were carried out by the researcher and eight extension officers of the Lagos State Agricultural Development Authority which took place during meeting days of the various farming communities. Data collected were analyzed using descriptive statistics such as cross tabulations, frequency and percentages while the hypothesis was tested using linear regression analysis. The variable of competition with other uses was investigated using rate of change of farm location, period of farming in the location, reasons for vacating land, activity replacing farmland and rate of change of use.

\subsection{Results and Discussion}

This section presents data collated from the field study, data analysis, hypothesis testing and discussions.

\subsection{Change of Use in Urban Farming}

The rate of change of use by respondents in the farming locations is summarized in Table 2. The study showed that change of use in the study area was occurring slowly especially in Volkswagen/Ojo and Idimu/Powerline and quite slowly or none at all in some other locations like PWD Ikeja and Iju/Grailland communities. In Adiyan, respondents changed their locations occasionally or spent an average of 4 to over 9 years on their farmlands. Land in Adiyan was government-owned and it did not find immediate use for it. Thus, farmers could stay long on their farmlands. Respondents in $\mathrm{Iju} /$ Grailland rarely changed their locations as their location was only accessible through Grailland making the land highly unattractive to land grabbers or developers. In Ayobo/Aboru, respondents also rarely changed their location as they were military personnel or wives of military personnel. Thus, urban farmers in the study area did not change their locations fast or regularly contrary to Omomoh and Adeofun's (2005) findings which noted that practitioners were affected by population growth, urban expansion and competition from other uses.

Table 2: Rate of Change of Use by Respondents

\begin{tabular}{lcccccc}
\hline $\begin{array}{l}\text { Farming } \\
\text { Communities }\end{array}$ & $\begin{array}{c}\text { Very } \\
\text { slowly }\end{array}$ & Slowly & Fast & Very fast & Missing values & Total \\
\hline Adiyan & $1(3.8 \%)$ & $3(11.5 \%)$ & $0 \%$ & $5(19.2 \%)$ & $17(65.4 \%)$ & 26 \\
Ayobo/Aboru & $0 \%$ & $2(11.5 \%)$ & $0 \%$ & $2(11.8 \%)$ & $13(76.5 \%)$ & 17 \\
Idimu/Powerline & $1(5.9 \%)$ & $6(35.3 \%)$ & $7(41.2 \%)$ & $1(5.9 \%)$ & $2(11.8 \%)$ & 17 \\
PWD Ikeja & $3(6.8 \%)$ & $0 \%$ & $0 \%$ & $0 \%$ & $41(93.2 \%)$ & 44 \\
Volkswagen/Ojo & $15(15.3 \%)$ & $37(37.8 \%)$ & $2(2 \%)$ & $7(7.1 \%)$ & $37(37.8 \%)$ & 98 \\
Festac Town & $6(4.7 \%)$ & $5(3.9 \%)$ & $1(0.8 \%)$ & $8(6.2 \%)$ & $9(84.5 \%)$ & 129 \\
\hline Total & $26(7.5 \%)$ & $53(15.2 \%)$ & $10(2.9 \%)$ & $23(6.6 \%)$ & $236(67.8 \%)$ & 348 \\
\hline
\end{tabular}


Table 3 further explained why respondents vacated their farmlands for competing uses. The Table noted that respondents were either forced out of their farmlands by eviction or harrasment or vacate due to high rents. That is, $19.5 \%$ of the respondents were forced out of their farmlands, $10.3 \%$ vacated voluntarily and $1.4 \%$ left due to high rents. Of those that were forced out, $64.7 \%$ were from Idimu and Powerline and $48 \%$ from Volkswagen and Ojo. 19.2\% of Adiyan respondents vacated voluntarily while $16.3 \%$ did same in Volkswagen and Ojo. These results showed that competition with other uses was posing serious land tenure challenges to the practice of urban crop farming. This therefore disagreed with Howorth et al. (2001) that urban crop farming was seen to be competing with other higher value urban land uses.

Table 3: Reasons Why Respondents Vacate Their Farm Lands

\begin{tabular}{lcccccc}
\hline $\begin{array}{l}\text { Farming } \\
\text { Communities }\end{array}$ & $\begin{array}{c}\text { Forced } \\
\text { out }\end{array}$ & $\begin{array}{c}\text { Vacated } \\
\text { voluntarily }\end{array}$ & $\begin{array}{c}\text { Due to } \\
\text { high rent }\end{array}$ & Other & $\begin{array}{c}\text { Missing } \\
\text { values }\end{array}$ & Total \\
\hline Adiyan & $1(3.8 \%)$ & $5(19.2 \%)$ & $1(3.8 \%)$ & $3(11.5 \%)$ & $16(61.5 \%)$ & 26 \\
Iju/Grailland & $0 \%$ & $0 \%$ & $0 \%$ & $0 \%$ & $17(100 \%)$ & 17 \\
Ayobo /Aboru & $0 \%$ & $2(11.8 \%)$ & $2(11.8 \%)$ & $0 \%$ & $13(76.5 \%)$ & 17 \\
Idimu/Powerline & $11(64.7 \%)$ & $0 \%$ & $11(64.5 \%)$ & $0 \%$ & $4(23.5 \%)$ & 17 \\
PWD Ikeja & $0 \%$ & $5(11.4 \%)$ & $0 \%$ & $0 \%$ & $39(88.6 \%)$ & 44 \\
VolksWagen/Ojo & $47(48 \%)$ & $16(16.3 \%)$ & $0 \%$ & $0 \%$ & $35(35.7 \%)$ & 98 \\
Festac Town & $9(7 \%)$ & $8(6.2 \%)$ & $0 \%$ & $4(3.1 \%)$ & $108(83.7 \%)$ & 129 \\
\hline Total & $68(19.5 \%)$ & $36(10.3 \%)$ & $5(1.4 \%)$ & $7(2 \%)$ & $232(66.7 \%)$ & 348 \\
\hline
\end{tabular}

This was affirmed by Reuther and Dewar (2005) that land shortage for urban crop farming would arise because of competition with housing development and other incompatible uses. The study thus, agreed with Omirin (2003) which noted that, "the fixity and scarcity of land results in intense competition and high value, which obviously goes beyond the reach of the urban poor'. Thus, urban farmers were unable to compete with other uses for first class or good locations and were therefore consigned to marginal and unproductive land such as steep slopes, rights of way, buffer zones, etc.

\subsection{Hypothesis Testing}

To further establish the effect of the constraint competition on the activity of urban farmers, the hypothesis that competition with other uses constraint in land accessibility had no significant effect on urban crop farmers' productivity in the study area was tested. The regression analysis in Table 4 indicated an $\mathrm{R}^{2}$ value of 0.035 implying that only $3.5 \%$ change in farmers' productivity was attributed to competition with other uses. The $t$-value of $-2.762(\mathrm{p}<0.05)$ presumed that the Null Hypothesis be rejected thus supporting the alternative hypothesis that, competition with other uses constraint in land accessibility, had a significant effect on urban crop farmers' productivity. As a result, the study established that a fall of 0.242 in farmers' productivity was expected for a unit increase in competition with other uses constraint and 4.197 represented the mean of farmers' productivity if the constraint competition with other uses was totally eliminated in the study area. It was therefore further established that farmers' productivity could be well enhanced if they were not forced out of their locations by eviction or harassment or imposition of high rents. They must be allowed to vacate voluntarily, provided with loans or funds to buy inputs as well as provided with documents that conferred security of tenure over their locations. The study therefore established that competition with other uses was a major constraint affecting urban crop farmers' productivity as they found solace with marginal and unproductive locations. 
Table 4: Regression Result of the Effect of Competition with other uses Constraint on Crop Farmers' Productivity

\begin{tabular}{lrccc}
\hline Variable & Estimate & Std. Error & \multicolumn{1}{c}{ t } & Sig. \\
\hline (Constant) & 4.195 & 0.175 & 23.986 & 0.000 \\
Competition with other uses & -0.242 & 0.088 & -2.762 & $0.006^{*}$ \\
$\mathrm{R}$ & 0.188 & & & \\
$\mathrm{R}^{2}$ & 0.035 & & & \\
Adjusted R & & & \\
Std. Error & 0.031 & & & \\
DW & 1.272 & & & \\
$\mathrm{~F}$ & 1.176 & & & \\
\hline$*$ Significant at 0.05 level & 7.628 & & &
\end{tabular}

\subsection{Conclusion and Recommendations}

The study evaluated the competition constraint as it affected land accessibility of urban farming in the Lagos metropolis particularly among some urban farming communities. It highlighted the importance of the activity in solving problems of food security, income generation and unemployment. Like other activities in the informal sector, urban farmers were found to be marginalized in their land accessibility and were too poor to compete with other uses of residential, commercial and industrial developments for land. The study showed that farmers were forced out (19.5\%) of their locations, $10.3 \%$ vacated voluntarily, $1.4 \%$ left due to high rents, $2.9 \%$ were unidentified and $67.8 \%$ were missing values. Farmers in the study area were found to be occupying marginal or unproductive lands that did not attract other competing uses. The test of hypothesis carried out, inferred that competition constraint significantly affected urban farmers' productivity as they were forced to farm in unproductive lands. The study consequently called for government support and promotion of the activity by providing agricultural lands in designated areas of the Lagos metropolis that are devoid of competition constraint characteristics.

\section{References}

Abiodun, J.O., (1997) The Challenges of Growth and Development in Metropolitan Lagos, Chapter 6 in The Urban Challenge in Africa. Growth and Management of its Large Cities, edited by C. Rakodi. United Nations University Press. Tokyo-New York-Paris. Retrieved 19/02/14 from http://archive.unu.edu/unupress/unupbooks/uu26ue/uu26ue00.htm\#Contents

Aina, O.S., Oladapo, A., Adebosin, W.G. and Ajijola, S., (2012). Urban Livelihood: Urban Agriculture Implication in Food Security, A Case Study of Ibadan Metropolis, Journal of Applied Hytotechnology in Environmental Sanitation, 1(4), pp.155-161.

Akinmoladun, O.I. and Adejumo, O.T., (2011). Urban agriculture in Metropolitan Lagos: An inventory of potential land and water resources. Journal of Geography and Regional Planning, 4(1), pp.9-19.

Angotti, T., (2015). Urban Agriculture: Long-Term Strategy or Impossible Dream? Lessons from Prospect Farm in Brooklyn, New York. [online] Public Health xxx, 1-6, Available at http://www.nycfoodpolicy.org/wp-content/uploads/2015/04/Angotti-Urban-Agriculture.pdf, http://dx.doi.org/10.1016/j.puhe.2014.12.008 [Accessed 18 Dec. 2016]

Asiama, S.O., (2005). Land Accessibility and Urban Agriculture in Freetown, Sierra Leone. Journal of Science and Technology. 25(2), pp.103-109.

Bello, M.O., (2007). Accessibility of Land as a Tool for Empowering the Low-Income Earner of the Informal Sector in Nigeria. [online] paper presented at FIG Working Week, Hong Kong, 13-17. Available 
https://www.fig.net/resources/proceedings/fig_proceedings/fig2007/papers/ts_7a/ts07a_01_bello_128 2.pdf. [Accessed 20 Aug. 2011]

Castles Magazine (2016). Property Sales/Letting. Realhouse Communications Limited, 50, 18-3. [online] . Available at www.castleswweekly.com. [Accessed 16 Dec. 2016]

Crush, J., Hovorka, A. and Tevera, D., (2011). Food security in Southern African cities: the place of urban agriculture, Progress in Development Studies, 11(4), pp.285-305. Doi: $10.1177 / 146499341101100402$

Drechsel, P. and Dongus, S., (2009). Dynamics and Sustainability of Urban Agriculture: Examples from sub-Saharan Africa. Integrated Research System for Sustainability Science, 5, pp.69-78. Doi: 10.1007/s11625-009-0097-x.

Foeken, D.W.J. and Owuor, S.O., (2000). Urban Farmers in Nakuru, Kenya. [online] City Farmers, Canada's Office of Urban Agriculture. Available at cityfarm@ unixq.ubc.ca [Accessed 06 March 2004].

Freeman, D., (1991). A City of Farmers: Informal Urban Agriculture in the Open Spaces of Nairobi, Kenya. McGill University Press, Toronto.

Howorth, C., Convery, I. and O'Keefe, P., (2001). Gardening to Reduce Hazard: Urban Agriculture in Tanzania. Land Degradation and Development. Land Degradation Development, 12(3), pp.285-291, doi: 10.1002/ldr.441

Kish, L., (1965): Survey Sampling. Wiley, New York.

Knowd, I., Mason, D. and Docking, A., (2006, June). Urban agriculture - The New Frontier. [online] Paper presented to Planning for Food Seminar, Vancouver. Available at http://sydneyfoodfairness.org.au/wp-content/uploads/2009/07/urban_ag.pdf. [Accessed 03 July 2010]

Lagos State Government -LASG (2015). Lagos State Population. [online] Available at http://www.lagosstate.gov.ng/pagelinks.php?p=6. [Accessed 19 Feb. 2015]

Merriam-Webster (2016). Learner's Dictionary. [online] Available at http://learnersdictionary.com/definition/competition. [Accessed 16 Dec. 2016]

Mougeot, J.A. L., (2000). Urban agriculture: Definition, Presence, Potentials and Risks, and Policy challenges, pp. 1-42 in Growing Cities, Growing Food, Urban Agriculture on the Policy Agenda, A Reader on Urban Agriculture edited by N. Bakker, M. Dubbeling, S. Gundel, U. Sabel-Koschella and H. de Zeeuw. Deutsche Stiftung Internationale Entwicklung (DSE). Feldafing, Germany

Moore, D., McCabe, G., Duckworth., \& Sclove, W.S., (2003). The Practice of Business Statistics. Freeman, New York.

Mosha, A.C., (2015). Urban Agriculture in Botswana. [on line] Commonwealth Journal of Local Governance, Issue 18, pp.48-67. Available at http://dx.doi.org/10.5130/cjlg.v0i18.4842, http://epress.lib.uts.edu.au/journals/index.php/cjlg/article/view/4842/5209. [Accessed 18 Dec. 2016].

Nasr, J. (1996). Agriculture as a sustainable use of urban land. Paper presented to Urban Planning and the Future of Urban Food Systems, ACSP/AESOP Conference, Toronto. July, 25-28.

Ndi, H.N., (2009) Population Growth and Urban Agriculture in Yaounde, Cameroon. Journal of Applied Social Sciences, 8(1\&2), pp.60-73.

Nirab, S., (2007) Investigation into Contractor's Bidding Decisions in Gaza Strip, Unpublished MSc Thesis, Islamic University, Gaza Strip.

Odudu, C.O., (2007). Mass Housing and Urban Agriculture - Better of Two Necessities in a Developing Country, pp.121-136 in Private Sector Driven Housing Delivery: Issues, Constraints, Challenges and Prospects edited by T.O. Nubi, M.M. Omirin and A.S. Afolayan. University of Lagos, Akoka, Lagos.

Odudu, C.O., Nubi, T.G., \& Omirin, M.M., (2015). An Analysis of Affordability of Land for Urban Crop farming in Lagos, Nigeria, The Lagos Journal of Environmental Studies, 7(5), pp.85-96 
Olayiwola, L.M., Adeleye, O.A. and Oduwaye, A.O., (2005) Correlates of Land Value Determinants in Lagos Metropolis, Nigeria. J. Hum. Ecol., 17 (3). pp.183-189.

Omirin, M.M., (2003). Issues in Land Accessibility in Nigeria, pp.49-70 in Land Management and Property Tax Reform in Nigeria edited by M.M. Omirin, T.G. Nubi \& S.A. Fawehinmi. University of Lagos, Lagos, Nigeria.

Omomoh, E. and Adeofun, C.O., (2005, October). An Assessment of Urban Agricultural Land Use Changes Using Geospatial Information System: A Case Study of Jos-Bukuru. [online] Paper presented at the Farm Management Association of Nigeria Conference, Asaba, Available at http://ageconsearch.umn.edu/bitstream/54393/2/An\%20assessment\%20of\%20Urban\%20Agricultural \%20Land.pdf. [Accessed 12 March 2010]

Oni, S.I., (2001). Urbanization and Transport Development in Metropolitan Lagos, pp.193-219 in Industrialization, Urbanization and Development in Nigeria 1950-1999 edited by M.O.A. Adejugbe. Concept Publications Ltd, Mushin, Lagos, Nigeria.

Oxford Advanced Learner's Dictionary-OALD (2001). Current English. S. Wehmeier (Ed.), Oxford University Press. $6^{\text {th }}$ Edition.

Reuther, S. and Dewar, N., (2005). Competition for the use of public open space in low-Income urban areas: the economic potential of urban gardening in Khayelitsha, Cape Town. Development Southern Africa, 23(1), pp.97-122. doi:10.1080/03768350600556273.

Sanyal, B., (1985). Urban Agriculture: Who cultivates and why? A case- study of Lusaka, Zambia. Food and Nutrition Bulletin, 7(3), pp.15-24

Tinsley, J., (2003) Urban Agriculture and Sustainable Livelihoods. Peace Review, 15(3), pp.295-299.

Ukaejiofo, A.N., (2010) Identifying Appropriate Tools for Land Governance in Nigeria, [online] paper presented at XXIV FIG International Conference, Sydney, Australia, April 11-16. Available at http://www.fig.net/pub/vietnam/papers/ts01b/ts01b_ukaejiofo_3643.pdf. [Accessed 20 Aug. 2011].

United Nations-HABITAT (2008, July). Land and Sustainable Food Production. [online]. Presented at $2^{\text {nd }}$ African Ministerial Conference on Housing and Urban Development, Abuja. Nigeria. Available at http://www.unhabitat.org/downloads/docs/amchud/bakg8.pdf. [Accessed 18 Aug. 2011]

van Veenhuizen, R., (2006). Cities Farming for the Future [online] Cities Farming for the Future. Urban Agriculture for Green and Productive Cities. Available at https://www.idrc.ca/en/book/citiesfarming-future-urban-agriculture-green-and-productive-cities. [Accessed 18 Dec. 2016]

Vélez-Guerra, A., (2004). Multiple Means of Access to Land for Urban Agriculture: A Case Study of Farmers' Groups in Bamako, Mali. [online] Cities Feeding People Report Series, Ottawa: IDRC, DECEMBER, 2004. Available at http://www.futurepolicy.org/fileadmin/user_upload/Axel/Urban_Farming/Urban_land_use.pdf. [Accessed 11 March 2012] 